\title{
ANALYSIS OF FLOOD DISASTER MITIGATION IN WEST SUMATRA
}

\author{
${ }^{*}$ Muhammad Hidayat ${ }^{12}$, Nurhasan Syah $^{23}$, Erianjoni ${ }^{12}$ \\ ${ }^{* 1}$ Department of Sociology, Universitas Negeri Padang - Indonesia \\ ${ }^{2}$ Doctoral Program of Environmental Science, Universitas Negeri Padang - Indonesia \\ ${ }^{3}$ Department of Civil Engineering, Universitas Negeri Padang - Indonesia \\ Email: hidayatantrop@fis.unp.ac.id
}

*Corresponding Author, Received: March 8, 2021. Revised: March 21, 2021. Accepted: May 20, 2021

\begin{abstract}
Watershed development based on sustainable development requires open management that ensures the continuity of the coordination process between related institutions. This development is characterized by cross-sectoral and multidisciplinary. This research problem answers about 1) What is the cause of flooding in West Sumatra?; 2) What are the alternative mitigations for the flood disaster management?; 3) What are the impacts of the flood?; and 4) What are the strategic steps that can be taken?. The research study uses the library method, which is based on data obtained from the Agency of Regional Disaster Management (BPBD) West Sumatra Province in 2019. The results of this study indicate that the principles of disaster mitigation in West Sumatra have not been fully implemented, such as before a disaster, during a disaster, and after a disaster.
\end{abstract}

Keywords: Disaster Mitigation, Flood, West Sumatra Province

\begin{tabular}{ll}
\hline (c) (i) (-) This work is licensed under the Creative Commons Attribution-ShareAlike 4.0 \\
International License
\end{tabular}

\section{INTRODUCTION}

A disaster is a natural or non-natural process that causes casualties, property and disrupts the order of life [1-3]. [4] adds geographically, Indonesia is located on the equator with the morphology from the mainland to the high mountains and is also an archipelago located at the confluence of four tectonic plates, namely the Eurasian plate, the Indo-Australian plate, the Philippine plate, and the Pacific plate. The movement of these tectonic plates causes the formation of earthquake paths, active mountain chains, and geological faults, which are prone to earthquakes, volcanic eruptions, landslides, and other disasters.

Disaster, according to Law No. 24/2007 concerning disaster management, is an event or series of events that threatens and disrupts people's lives and livelihoods caused, both by natural factors and/or non-natural factors as well as human factors resulting in human casualties, environmental damage, property loss, and psychological impact. From this definition, it is known that humans are one of the factors causing disasters [5]. In connection with the recent floods in West Java, most of them occur due to human behavior, such as: developing in protected areas, converting land from the forest or protected swarms to plantations or even tourist areas, and dumping garbage into rivers. In areas prone to disasters, this community behavior must be directed by the government in the context of disaster management [6].

Mitigation is a series of efforts to prevent and reduce disaster risk. The form consists [1-4] First, structural mitigation, namely risk reduction efforts through the application of solutions designed in the form of physical environmental changes; second, non-structural mitigation includes modification of processes of human or natural behavior through regulations, education programs, and community awareness. In the Disaster Management Law, mitigation is carried out through 1) Implementation of spatial planning means that spatial planning must be the basis for every activity carried out. The Regional Spatial Plan must be the basis for spatial use in each region; 2). Arrangements for development, infrastructure development, building layout, the government must control the development in its territory so as not to cause disaster risk, and control is carried out by making arrangements for the construction of disaster-resistant buildings and infrastructure and ensuring that development is not carried out in disaster-prone areas or does not permit development that has the potential to cause disaster; and 3) Providing education, counseling, 
and training, both conventional and modern, educating the public about disasters is very important and can reduce the risk of victims because one of the causes of disasters is activities carried out by humans. Through this education, the community will understand what activities or behaviors might cause a disaster so that awareness is formed to stay away from behaviors that have the potential to cause disasters. In addition, the community will also understand what should and should not be done when faced with a disaster.

West Sumatra Province has many areas that have the potential for disasters. Based on the 20082012 West Sumatra Disaster Management Plan (RPB), West Sumatra Province has the potential for natural disasters, as follows: earthquakes, tsunamis, floods, storms/tornadoes, tidal waves, drought, landslides, volcanic eruptions, forest and land fires, beach abrasion. However, the impact is wide, and the potential damage caused is usually caused by the following disasters: earthquakes, tsunamis, floods, landslides, volcanic eruptions, and fires [5]. Based on data on disaster-prone areas of West Sumatra in 2016, West Sumatra province has four major potential disasters, namely landslides, flash floods/floods, tsunamis, and land earthquakes, and sea earthquakes [6].

The same thing was stated by [7], which states that one of the areas known as disaster supermarkets and the country of one thousand and one disasters is West Sumatra. He mentioned that there are at least seven types of potential disasters in West Sumatra, namely earthquakes, tsunamis, volcanic eruptions, landslides, floods, coastal abrasion, storms, and others. West Sumatra, or in particular the island of Sumatra, is generally crossed by the Indo-Australian fault. The plate passes through the Indonesian Ocean, which is on the western side of the island of Sumatra. Usually, the areas along the path of the earth's plate have active volcanoes. This displacement of the earth's plate can cause vibrations on the earth's surface, and if the shift is on the seabed, it will cause a movement of seawater which can cause large waves to land or a tsunami [8]. [9, 10], in their research, states that the Province of West Sumatra is one of the areas in the world most at risk if it is hit by the tsunami. Based on the Disaster Risk Assessment of the Province of West Sumatra in 2014-2018, the level of disaster risk in the Province of West Sumatra based on BPBD data (2019), the biggest disaster that occurred in West Sumatra was flooding 154 times.

Flood is the second biggest disaster in Padang City [11]. Thus, flooding is one of the major disasters in West Sumatra which can be stated based on the flood map that occurred in 2019 as follows.

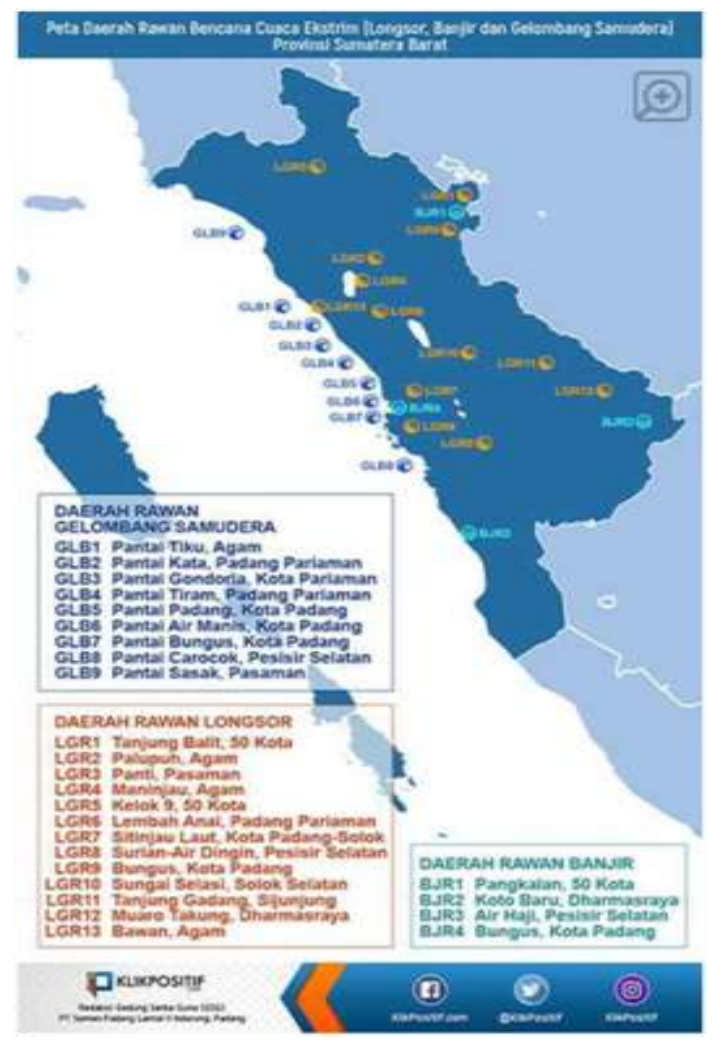

Fig.1 Disaster of West Sumatra 
Based on the description above, several problems can be raised 1) What causes flooding in West Sumatra?; 2) What are the alternatives to mitigate flood disaster management?; 3) What are the impacts of the flood?; and 4) What are the strategic steps that can be taken?

\section{RESEARCH METHODS}

This research uses the literature method. In data collection, this study determines the data sources and the location where these data sources can be found and researched. In contrast to field research, the location of data collection for library research is much broader and does not even recognize spatial boundaries [12]. The research setting is the benchmark in which the location is carried out. Before mentioning the location of the research, it is a good idea to mention the specific characteristics of library research to distinguish the set of library research from other research such as field research. Library research has several special characteristics, among others; firstly, this research deals directly with text or numerical data, not with the field or eyewitnesses, in the form of events, people, or other objects. Second, data is readymade, meaning that researchers do not go anywhere except the only face-to-face with sources already in the library. Third, library data is generally a secondary data source, in the sense that the researcher obtains data second-hand, not firsthand in the field. Fourth, the condition of the data in the library is not divided by time and space [13]. This research is about 1) What causes flooding in West Sumatra? 2) What are the alternatives to mitigate flood disaster management? 3) What are the impacts of the flood?; and 4) What are the strategic steps that can be taken?.

\section{RESULTS AND DISCUSSION}

\subsection{Causes of Floods}

Recently, the weather in Indonesia, especially in the provinces. Sumatra is very extreme. The very high intensity of rainfall has caused water overflows everywhere, starting from the road to entering residential areas, thus disrupting activities. A flood is a process of shaming river water to the mainland so that it can cause loss of people's property and can cause casualties. Floods can also damage buildings, facilities, and infrastructure, the environment, and destroy the order of people's lives. For this reason, various parties need to pay attention to things that can cause flooding and anticipate it as early as possible, to minimize the losses it may cause [14]. Several other factors cause flooding, namely: Insufficient river channel capacity., Deforestation., The existence of sediment deposits (delta) at the mouth of the river., Flood area, which is a lowland area., Waste disposal into rivers., and Untreated drainage.

The size of the drainage is not by the discharge that is accommodated. Various parties have done many ways to cope with the flooding that occurred in Indonesia, especially in the Province of West Sumatra. But the existing solutions have not been able to solve the problem effectively. Flood solutions will be sought and studied if a large flood has occurred in that place. The anticipation and mitigation of floods should have been carried out before the place was carried out in the construction stage. One of the ways of dealing with floods that will be discussed in this written idea is by making improvements to the drainage system. The purpose of making this idea is to minimize flood-prone areas in the city of Padang and find alternative solutions to prevent flooding. So that people can avoid losses caused by the flood, such as casualties, disease, property loss, and environmental pollution.

\subsection{Flood Disaster Mitigation}

There are several alternatives for Flood Management/Mitigation, including.

1. Law enforcement for residents who litter. The prohibition of littering or improperly stipulated in Law No.18/2008 on waste management. Even though the sanctions given are very heavy, the phenomenon of people littering is still very much visible. Especially disposing of garbage on roadsides and in rivers when it rains, the garbage will be carried away by river currents and will cause flooding.

2. Making infiltration wells Infiltration wells function to collect water when it rains so that it will reduce stagnant water that occurs. If one infiltration well can accommodate several water flows, of course, if each resident's house has an infiltration well, there will be a lot of water discharge that can be accommodated by it; this will reduce the risk of flooding that will occur due to rain [15]. In the Province of West Sumatra itself, the construction of infiltration wells is still very few; this is due to the lack of knowledge of the local community and the lack of socialization from the government.

3. It increases the use of paving blocks. For parking areas and trails, it is recommended to use paving blocks because the material is a permeable layer (absorbs water) which is environmentally friendly. The use of paving blocks has functioned so that when it rains, water absorbs it more easily into the ground, compared to using asphalt or concrete, which stagnates the water. 
4. Increase green areas The availability of green open spaces, especially in big cities, should be at least $30 \%$ of the city area.

But in reality, the existing green open space only reaches $10 \%$. Green open space can be an area for water absorption when it rains, and of course, this can be a way to deal with flooding. Green open space, for example, is like tree planting, which can be done in yards, schools, offices, and other public places. The existence of trees or plants can support the creation of a green city, benefit health and create clean air, reduce air pollution, become an area for play, sports, a place for public communication, and reduce the amount of rainwater that flows on the ground and can cope with flooding. Not building settlements around the river As a result of the high level of urbanization and population density, on the one hand, the availability of land for settlement and the low economic level of the community causes many people to use green areas and watersheds as places of settlement [16, 17]. As a result, the ability of green areas to absorb water and the capacity of rivers to receive the amount of flowing water is reduced.

\subsection{The Impact of Flood Management as Solution for the Environment and Social Life of the Community}

Floods that occur in West Sumatra Province must be a major concern for the government because the floods that have occurred have inundated cross-urban roads, such as J1. Khatib Sulaiman, Lolong, Mount Pangilun, Ampang, Air Pacah in the Province of Sumbard and other areas. Every time it rains, floods will inundate the road, this causes congestion when it rains. [11] adds the impact of this flood resulted in the disruption of residents' activities. Floods that occur when the rain comes are a familiar phenomenon to the community. Not only in low-lying areas, but floods also inundated roads and population complexes. The flood that occurred was caused by none other than the drainage channel that was not smooth.

The steps that must be taken to overcome the impact of flooding are.

1. Dredge the drainage if there is a pile of sedimentation. If the sediment that has accumulated in the drainage is not dredged, the volume of the drainage cross-section that serves to accommodate the discharge will decrease.

2. Recalculating the existing drainage dimensions in West Sumatra Province because many of the drainages built do not match the discharge accommodated by the drainage dimensions. This is caused by very extreme weather changes and the lack of rainfall data used. This is because the location of the stations in the Province of West Sumatra is very far away and is not by the provisions. Where in this provision, the distance between stations is 10 $\mathrm{km}-30 \mathrm{~km}$, but the distance between stations is far from the stipulation, namely $\pm 200 \mathrm{~km}$.

3. Make a strong appeal to the people of the Province of West Sumatra, especially those who live in areas close to the drainage, to pay attention to cleanliness and maintain the existing drainage so that no garbage is washed away and accumulates in the drainage and wild plants that grow in the drainage can cause flooding.

4. It does not interfere with the road drainage function. A case that is familiar to us is erecting a building above the drainage which can cause the drainage to malfunction. For example, drainage is used to build stalls and huts for selling on it. The impact is that the drainage, which functions to drain water that is stagnant in the road body to be disposed of into the drainage, becomes clogged due to the garbage from people selling.

5. When building a good highway, it should be the drainage that is built first, not the road. But in reality, what happens in the field is that the road itself is built, not the drainage. The worst thing that happens is that the road will be built without any drainage. This condition is often found in the province of Sumbardi on roads in residential areas such as complexes or small roads.

This condition will have a bad impact and will be the main cause of flooding because the rainwater that falls does not have a place to collect the water and flow it to the disposal site. So that when it rains a little, the water will immediately inundate the road, which will interfere with community activities. This is a solution that the author can put forward so that it can be useful for residents of the Province of West Sumatra, especially areas that have become frequent floods, such as Khatib Sulaiman, Lolong, Lapai, Air Pacah, Ulak Karang, and other areas. If this solution is implemented properly, it can reduce the impact caused by flooding.

\subsection{Strategic Measures for Flood Management}

The strategic steps that can be taken for flood prevention efforts include.

1. The role of the government is indispensable in overcoming the problem of floods. The government should not only provide criticism of every existing flood problem but the government must get involved directly in dealing with this problem. Handling is not only 
carried out during floods, but it needs smart efforts to deal with it before the flood occurs.

2. The role of local governments cannot be denied in overcoming this flood problem. Participation and the active role of local governments are crucial for success in flood prevention efforts. Smart solutions from local governments are needed in flood prevention. The government must think about the steps taken to prevent and solve any existing flood problems.

3. The role of the community cannot be separated in overcoming this flood problem. The community is not just standing by in the face of every flood problem. It needs activeness and the role of the community so that the flood problem is not only a problem for the government. So that all parties must work together to be able to overcome all existing flood problems.

4. It is necessary to disseminate information to all levels of society in general about the improvement of the drainage system and maintenance of the drainage system. And also carry out activities that are useful for flood prevention, such as improving the drainage system, planting 1000 trees, and constructing infiltration wells.

\section{CONCLUSION}

Mitigation of floods is carried out in the form of pre-disaster 1) structuring river flow areas in an integrated manner and according to land functions; 2) development of monitoring and early warning systems in rivers that often cause flooding; 3 ) local governments make infiltration wells, dams, sirens; 4) not building houses and settlements along the river; 5) not throwing garbage into the river and routinely conducting river dredging programs; 6) installing pumps for areas lower than sea level; 7) greening upstream river areas. Must always be carried out, accompanied by reduced activity in parts of the river prone to flooding and; 8) storing important documents in aluminum suitcases or the like (not easily damaged by water and soil) and placing them in a safe place. During a Disaster, it is carried out 1) turn off the electric current in the house or contact the National Electric Company to turn off the electricity in the affected area; 2) Move electronic goods and other items that are easily damaged to a safe place; 3) Livestock are sent to the place. Which is not easily accessible by water and landslides for a while; 4) Avoid walking near waterways to avoid being swept away by flood currents; 5) evacuating to a safe place; 6) if the water keeps running low, contact the closest relative or related agency to ask for help; 7) construction of earthquake and flood-resistant houses, (12) other human actions that can cause landslides and floods. After a disaster 1) clean the house as soon as possible, especially other parts of the lotus, then use antiseptic to kill germs; 2) find and prepare to clean water to prevent diarrhea; 3 ) be aware of the possibility of poisonous animals or animals that spread disease; and 4) always be vigilant in case of subsequent flooding.

\section{ACKNOWLEDGEMENTS}

This writing this literature reviews can be carried out smoothly, because of the help and cooperation of various parties. Therefore, the author would like to thank Prof. Dr. Dedi Hermon, MP as the Deputy Director II of the Postgraduate Universitas Negeri (also chairman of the course of disaster risk management, disaster mitigation, and Geography Information Systems/GIS in the Doctoral Program in Environmental Science, Universitas Negeri Padang) who have provided the opportunity and time to sharpen the academic ability my, especially in the field of disaster environmental.

\section{REFERENCES}

[1] Hermon D. Geografi Lingkungan: Perubahan Lingkungan Global. Padang: UNP Press, 2010.

[2] Hermon D. Geografi Bencana Alam. Jakarta: PT RajaGrafindo Persada, 2015

[3] Hermon D. Mitigasi Perubahan Iklim. Jakarta: PT RajaGrafindo Persada, 2016

[4] Hermon D. Climate Change Mitigation. Jakarta: PT RajaGrafindo Persada, 2017.

[5] Hermon D. Mitigation and Adaptation: Disaster of Climate Change. India: Sara Book Publication, 2019

[6] Peraturan Kepala Badan Nasional Penanggulangan Bencana Nomor 15 Tahun 2012 Tentang PUSDALOPS-PB.

[7] Hidayat B., and Rasadi A. Disaster-based participatory development planning. In E3S Web of Conferences, 2020, 156, p. 01010.

[8] Kusumaningtyas R., and Chofyan I. Pengelolaan hutan dalam mengatasi alih fungsi lahan hutan di Wilayah Kabupaten Subang. Jurnal Perencanaan Wilayah dan Kota, 2013, 13(2).

[9] Alhadi Z., and Sasmita S. Kesiapsiagaan Masyarakat Kota Padang Dalam Menghadapi Resiko Bencana Gempa Dan Tsunami Berbasis Kearifan Lokal (Studi Kesiapsiagaan Terhadap Resiko Bencana). Humanus, 2014, 13(2), 168-179.

[10] Erianjoni., Hermon D., Dewata I., and Putra A. A Survival and Adaptation of the Community in Potentially Disaster Area of Sinabung Volcano Eruption in Karo 
Regency-Indonesia. Talent Development and Excellence, 2020, 12(3s), 2134 - 2140.

[11] Putra A., Triyatno., and Husrin S. Analisa Bencana Banjir di Kota Padang (Studi Kasus Intensitas Curah Hujan Kota Padang 19802009 dan Aspek Geomorfologi). Prosiding Seminar Sains Atmosfer, 2013, 24-33

[12] Hidayat, M. (2018). Problematika Internal Nelayan Tradisional Kota Padang: Studi Faktor-faktor Sosial Budaya Penyebab Kemiskinan. Jurnal Socius: Journal of Sociology Research and Education, 4(1), 3140.

[13] Ermayanti., Effendi., and Hidayat $M$. Teknologi Penangkapan Ikan pada Masyarakat Nelayan di Nagari Pasar Lama
Air Haji, Kecamatan Linggosari Baganti, Kabupaten Pesisir Selatan. Jurnal Antropologi: Isu-Isu Sosial Budaya, 2015. 17(1), 23-38.

[14] Kodoatie, R. J. Sugiyanto 2002 Flood causes and methods of control in an environmental perspective.

[15] Hermon D. Mitigasi Bencana Hidrometeorologi: Banjir, Lonsor, Ekologi, Degradasi Lahan, Puting Beliung, Kekeringan. Padang: UNP Press, 2012.

[16] Putra A. Studi Erosi Lahan Pada DAS Air Dingin Bagian Hulu di Kota Padang [Skripsi]. Jurusan Geografi | Fakultas Ilmu Sosial | Universitas Negeri Padang, 2012. 